\title{
FINANCIAL MARKET IN THE CZECH REPUBLIC AND HU- MAN CAPITAL INVESTMENT: PRIVATE FINANCING OF HIGHER EDUCATION
}

\author{
Václav URBÁNEK, Kateřina MARŠíKOVÁ-NEPOLSKÁ*
}

\begin{abstract}
:
In this paper we investigate the possibilities of investing in human capital at the financial market of the Czech Republic. In particular, the conditions for this investment would be different among individuals due to the difference of bequest amount and the credit market condition in financing the money for human capital investment or education. There is also higher risk for possible investors in determining individuals' income and in adverse selection. Our paper deals with the possibilities of avoiding these problems and we use our data from the survey of Czech universities students' earnings expectations collected during the years $2002-2004$. We use expected returns to education of the Czech higher education students as a benchmark for creating student loans and human capital contracts models. Financial market and institutions should offer different ways of financial assistance. However, financial market of the Czech Republic is not prepared for this type of investment.
\end{abstract}

Keywords: higher education, private universities, returns to investment, human capital contracts, tuition fee

JEL Classification: I22, J24, J41

\section{Introduction}

After 1990, the Czech higher education system has been broadly liberalized: the establishment of new universities has been enabled, the system of financing has changed and the autonomy of individual institutions has grown. However, financing of higher education has remained one of the key issues of the Czech governments since the split with Slovakia and establishment of the independent Czech Republic in 1992, to the present time. The development of Czech higher education system also involved an expansion of the numbers and capacities of higher education institutions resulting from a strong political pressure to increase the numbers of

*) Technical University of Liberec, Faculty of Economics, Hálkova 6, CZ - 46117 Liberec (e-mail: vaclav.urbanek@vslib.cz; katerina.marsikova@vslib.cz).

$\left.{ }^{\star *}\right)$ The paper is a part of the research grant of the Grant Agency of the Czech Republic No. 402/04/ 0039 and was presented at the 60th Congress of the International Institute of Public Finance, Milan, August 2004. 
enrolled university students. This pressure was obviously result of both competition of internal political forces and of political and cultural impact from Western European countries and the USA which were criticizing the low enrolment rates of the Czech higher education system. The problems of limited public funds for the universities and the possibility to supplement them by private finances are at the time being one of most important economic and political challenges. There are some solutions of private funding of the university studies and one of them are human capital contracts discussed in the following text.

\section{Higher Education Funding}

The transformation of the state higher education institutions into the public institutions in 1998 has altered fundamentally their financial management, as regards both property and budgeting. It is presumed that the basic part of the budget of a public higher education institution will continue to consist of a state subsidy. There should also be more implementation of other incomes, yields from property, and other income from the state budget: from the state funds and the community budget, yields from auxiliary activities, incomes from gifts and bequests and from various study fees. However, these fees are very limited legally and basically there are no tuition fees at the public and state higher education institutions in the Czech Republic.

Private higher education institutions are obliged according to law to ensure funding for their activities. The Ministry of Education, Youth and Sports may provide such an institution with a subsidy only in case that it acts as a non-profit institution. Similar criteria to those valid for a public higher education institution are used to determine the level of the subsidy in such a case. Private higher education (HE) institutions are almost fully dependent on the tuition fees paid by their students. The level of tuition fees is quite different and we can assume that the amount paid by the students at particular institution reflects the demand for this type of education, presumed quality of education and similar factors.

The external funds for higher education - public funds, grants, sponsors' money, international aid for higher education, etc. - are more and more limited in the developed countries ${ }^{1)}$ and also in the countries in transition from predominantly stateowned means of production and state-controlled economies to market-oriented economies with substantial private ownership. At the same time, the numbers of enrolled students are growing and it creats all the more pressure on the university funding. All that means that cost sharing has an increasing prominence - meaning that there is a shift of at least some higher education costs from governments and taxpayers to students and their parents.

There is also strong link between investment to education and economic growth. When we put it simply, we can see that according to the new endogenous growth models and Solow models augmented with human capital, education and knowledge have central role in the growth process. Due to the developments of theoretical insights offered by these models and due to the wave of empirical research that gave these models empirical relevance, the significance of human capital created through education for sustainable economic growth has been identified. Moreover, it is now widely accepted that government policies aimed at human resource development through education are critically important to achieving higher sustainable growth rates (see Barro, 2004).

1) We mean the countries organized in the OECD by the term developed countries. 
Table 1

\section{List of Private Higher Education Institutions in the Czech Republic in 2003}

\begin{tabular}{|c|c|c|}
\hline Private Higher Education Institution & Field of study (main) & $\begin{array}{l}\text { Tuition/year } \\
\text { in CZK }\end{array}$ \\
\hline Akademie Sting & Taxation, financial control & 36,000 \\
\hline Anglo-americký institut liberálních studií & $\begin{array}{l}\text { Social sciences and } \\
\text { humanities }\end{array}$ & 84,000 \\
\hline Bankovní institut - vysoká škola a.s. & $\begin{array}{l}\text { Bank management, } \\
\text { insurance }\end{array}$ & 50,000 \\
\hline Evropský polytechnický institut & Finance, commercial law & 30,000 \\
\hline Institut restaurování a konzervačních technik & Arts conservation & 35,000 \\
\hline $\begin{array}{l}\text { Literární akademie - soukromá vysoká škola } \\
\text { J. Škvoreckého }\end{array}$ & Creative writing & 49,500 \\
\hline Mezinárodní baptistický teologický seminář EBF & Theology & n.a. \\
\hline Pražská vysoká škola psychosociálních studií & Psychology, psychotherapy & 50,000 \\
\hline Pražský technologický institut, o.p.s. & $\begin{array}{l}\text { Transport, ecology, } \\
\text { construction }\end{array}$ & 38,000 \\
\hline Soukromá vysoká škola ekonomických studií, s.r.o. & Management & 56,000 \\
\hline Středočeský vysokoškolský institut, s.r.o. & n.a. & n.a. \\
\hline ŠkodaAuto Vysoká škola & Business administration & 39,000 \\
\hline University of New York in Prague & $\begin{array}{l}\text { Marketing, finance, } \\
\text { public relations }\end{array}$ & 90,000 \\
\hline Vysoká škola aplikovaného práva & Law & 50,000 \\
\hline $\begin{array}{l}\text { Vysoká škola cestovního ruchu, hotelnictví } \\
\text { a lázeňství }\end{array}$ & $\begin{array}{l}\text { Tourism, hotel } \\
\text { management }\end{array}$ & 120,000 \\
\hline $\begin{array}{l}\text { Vysoká škola ekonomie a managementu, } \\
\text { Ústí nad Labem }\end{array}$ & $\begin{array}{l}\text { Economics, business } \\
\text { administration }\end{array}$ & 50,000 \\
\hline Vysoká škola finanční a správní & Economics, management & 40,000 \\
\hline Vysoká škola hotelová & $\begin{array}{l}\text { Tourism, hotel } \\
\text { management }\end{array}$ & 65,000 \\
\hline Vysoká škola J. A. Komenského & Education & 38,000 \\
\hline Vysoká škola K. Engliše v Brně & Management & 35,000 \\
\hline Vysoká škola Karlovy Vary & Public administration, law & 40,000 \\
\hline Vysoká škola manažerské informatiky a ekonomiky & Economics, informatics & 64,000 \\
\hline Vysoká škola mezinárodních a veřejných vztahů & $\begin{array}{l}\text { Diplomatic services, } \\
\text { economics }\end{array}$ & 68,000 \\
\hline Vysoká škola obchodní & Tourism & 46,000 \\
\hline Vysoká škola podnikání & Informatics, management & 30,000 \\
\hline Vysoká škola v Plzni & Nurses, physiotherapy & 24,000 \\
\hline Vysoká škola veřejné správy a mezinárodních vztahů & Law, public administration & 55,000 \\
\hline Západomoravská vysoká škola Třebíč, o.p.s. & $\begin{array}{l}\text { Applied science and } \\
\text { informatics }\end{array}$ & 67,000 \\
\hline Academia Rerum Civilium & Political science & n.a. \\
\hline
\end{tabular}

Note: At present, average monthly salary in the Czech Republic is about CZK 17,000, it means about EUR 533. At the same time, average yearly tuition fee at the private HE institution is CZK 51,000, it is about EUR 1,600. The average yearly tuition fee at the private HE institution is about three average monthly salaries.

Source: Ministry of Education, Youth and Sports of the CR. 


\section{Sharing of Higher Education Costs}

The debate about funding higher education is going for many years. One of the biggest problems for students in higher education is how to pay for it. Education systems are different and also possibilities of financial assistance vary a lot. There is usually a large financial help from the state but even if there is not any tuition fee many students look for some way how to cover other costs (living costs, food, studying materials). At the same time, the government support, either for students and their families or directly for educational institutions, suffers from limited resources.

There is a question if the state should invest more to the higher education because of importance of human resource development for economic growth. Barro (2004) shows that both theoretical concepts and empirical results prove this importance, whence human capital in the models is included as education, experience and health. Modern states usually spend around $1.2 \%$ gross domestic product (GDP) on tertiary education (see OECD, 2003). Educational expenditures are usually included to the government consumption and they are not defined as investment (i.e. investment in human capital).

Financial market and institutions should offer different ways of financial assistance as loans, scholarships, grants, etc. Most OECD countries support educational activity by offering financial assistance to individuals during their tertiary studies. Indeed, in the absence of government intervention, investment in human capital is difficult to finance with loans for persons without some collateral. Such financial support is generally limited to tertiary education, but some countries, such as the United Kingdom, Sweden, Denmark and Canada, have also made assistance available to students at the upper-secondary level under certain circumstances. Private foundations in some countries also offer financial assistance to students as a condition for being tax-exempt. Student loan and grant arrangements differ significantly

Table 2

Options for Financing of Education

\begin{tabular}{|l|l|}
\hline Cost-sharing instrument & Examples \\
\hline Traditional loan & Numerous \\
\hline Human capital contract & My Rich Uncle \\
\hline Graduate tax & \\
\hline Income-contingent loan & $\begin{array}{l}\text { Australia, Ghana, Hungary, Namibia, } \\
\text { New Zealand, Sweden, United Kingdom }\end{array}$ \\
\hline Subsidization instrument & Examples \\
\hline $\begin{array}{l}\text { Voucher and other demand-side financing } \\
\text { mechanisms }\end{array}$ & $\begin{array}{l}\text { Bangladesh, Chile, Guatemala, Netherlands, } \\
\text { Pakistan, Sweden }\end{array}$ \\
\hline Entitlement & $\begin{array}{l}\text { Theoretical, but U.S. Gl Bill and Brazil's } \\
\text { Bolsa Escola comes close; numerous } \\
\text { student loan schemes }\end{array}$ \\
\hline Individual learning account & $\begin{array}{l}\text { Netherlands, Scandia (Sweden - public and } \\
\text { private initiatives), Spain, Sweden } \\
\text { (proposed), Switzerland, United Kingdom } \\
\text { (suspended) }\end{array}$ \\
\hline Education savings account & Canada \\
\hline Learning tax credit & United States \\
\hline
\end{tabular}

Source: Patrinos, 2004. 
across countries in terms of the extent of income and asset testing of both - students and their parents, the amount of financial assistance, and the interest rate and repayment schedules of loans. Table 2 introduces selected options for financing of education.

In connection with students loans (either classical commercial bank loans or income contingent loans), we should also look at the theories of income and consumption/savings, especially to the theory of permanent income presented in 1957 by Milton Friedman. This theory postulates that consumers are forward-looking and base their consumption decisions not on current income but on the expected discounted value of lifetime resources which is their permanent income.

\section{Human Capital Contracts}

As universities and other higher education institutions continue to increase their tuitions and fees, more students and their families will invest even larger portions of their income in higher education and many will incur large amounts of debt. An alternative way to pay for higher education is through human capital contracts - a private, market-oriented alternative to loans. Students obtain human capital contracts in much the same way as they apply for student loans currently, except for the amount to be repaid, which is flexible, based on the student's salary after graduation.

The theory of human capital assumes that the choice of a type of education, its length and a field of study depends on returns of financial means of this investment. If the individual decides to educate, he or she must invest some money. It is possible to do it directly (direct cost of education - costs of living, transport, tuition) or indirectly (opportunity costs - lost salary which you can get if you work instead of studying). The question is "Why do the people study than"? Probably because they expect the return of all their investments and in the future even appreciation of money they spent for their education.

On the data from the questionnaire we tried to analyse correlation between these two files of data expectations and also compared the data from two sequential academic years 2001/2002 - 2002/2003.

The questionnaire had similar structure in both academic years and in the academic year 2002/2003 involved also questions about incomes of parents. These variables should help to identify differences between estimations of students private and public schools. In the second part of the questionnaire students are asked what their expectations of income straight after graduation in their first job and than after 10-year experience, on minimum, average and maximum level. We also asked about the level of earnings they would expect if they have only secondary level education.

We gained our data from the questionnaire, which was addressed to students of the first year at public and private universities in academic years 2001/2002 and $2002 / 2003$. We took a random sample of two groups of universities - private and public, which are specialized in economic studies and one of them in hotel services area. Both groups included regional and Prague universities. The survey was addressed to 542 respondents, 78 from private universities, and 464 from public universities in the academic year 2001/2002 and to a similar sample of students in academic year 2002/2003 - 572 respondents, 60 from private universities, and 512 from public universities. Respondents were questioned personally and the filling of the questionnaire took approximately 20 minutes.

As we can see from the Tables 3 and 4 at private universities in both years the number of male in the file of respondents (52.6\%, resp. $54.0 \%$ ) slightly outweighs. In public universities there is only (38.0\%, resp. $30.0 \%)$ of male. 
Table 3

Structure of Respondent's File in Academic Year 2001/2002

\begin{tabular}{|l|c|c|c|c|}
\hline \multirow{2}{*}{ Gender } & \multicolumn{4}{|c|}{ Number of respondents } \\
\cline { 2 - 5 } & \multicolumn{2}{|c|}{ Private universities } & \multicolumn{2}{c|}{ Public universities } \\
\cline { 2 - 5 } & Absolutely & Relatively in \% & Absolutely & Relatively in \% \\
\hline Male & 41 & 52.6 & 174 & 37.5 \\
\hline Female & 37 & 47.4 & 290 & 62.5 \\
\hline Total & 78 & 100.0 & 464 & 100.0 \\
\hline
\end{tabular}

Source: Own survey.

Table 4

Structure of Respondent's File in Academic Year 2002/2003

\begin{tabular}{|l|c|c|c|c|}
\hline \multirow{2}{*}{ Gender } & \multicolumn{4}{|c|}{ Number of respondents } \\
\cline { 2 - 5 } & \multicolumn{2}{|c|}{ Private universities } & \multicolumn{2}{c|}{ Public universities } \\
\cline { 2 - 5 } & Absolutely & Relatively in \% & Absolutely & Relatively in \% \\
\hline Male & 34 & 54.0 & 152 & 30.0 \\
\hline Female & 29 & 46.0 & 358 & 70.0 \\
\hline Total & 63 & 100.0 & 510 & 100.0 \\
\hline
\end{tabular}

Source: Own survey.

From these two figures we can see that the data are comparable and the sample of students are very similar. There is a detailed description of data from the questionnaire from academic year 2001/2002 in the Table 5. The modus value for each

Table 5

Description of the Data from Questionnaire in 2001/2002

\begin{tabular}{|l|c|c|c|c|c|c|c|c|}
\hline \multirow{3}{*}{$\begin{array}{l}\text { Characte- } \\
\text { ristics }\end{array}$} & \multicolumn{7}{|c|}{ Public universities } & \multicolumn{3}{c|}{ Private universities } \\
\cline { 2 - 10 } & \multicolumn{2}{|c|}{ Male } & \multicolumn{2}{|c|}{ Female } & \multicolumn{2}{c|}{ Male } & \multicolumn{2}{c|}{ Female } \\
\cline { 2 - 9 } & Graduates & $\begin{array}{c}10 \text {-year work } \\
\text { experience }\end{array}$ & Graduates & $\begin{array}{c}10 \text {-year work } \\
\text { experience }\end{array}$ & Graduates & $\begin{array}{c}10 \text {-year work } \\
\text { experience }\end{array}$ & Graduates & $\begin{array}{c}\text { 10-year work } \\
\text { experience }\end{array}$ \\
\hline Average & 20,587 & 48,552 & 16,600 & 30,969 & 21,126 & 46,720 & 19,392 & 34,851 \\
\hline $\begin{array}{l}\text { Mean signed } \\
\text { error }\end{array}$ & 545 & 5,897 & 337 & 1,748 & 1,504 & 5,636 & 1,338 & 4,157 \\
\hline Median & 20,000 & 35,000 & 15,000 & 27,250 & 19,000 & 35,000 & 17,000 & 28,000 \\
\hline Modus & 20,000 & 30,000 & 15,000 & 20,000 & 15,000 & 30,000 & 15,000 & 30,000 \\
\hline $\begin{array}{l}\text { Standard } \\
\text { deviation }\end{array}$ & 7,271 & 77,789 & 5,732 & 29,766 & 9,630 & 36,087 & 8,140 & 25,285 \\
\hline Variance & $52,868,157$ & $6,051,089,795$ & $32,853,287$ & $886,023,255$ & $92,741,890$ & $1,302,250,610$ & $66,265,766$ & $639,317,568$ \\
\hline $\begin{array}{l}\text { Number of } \\
\text { respondents }\end{array}$ & 174 & 174 & 290 & 290 & 41 & 41 & 37 & 37 \\
\hline
\end{tabular}

Source: Own calculations. 
variable express the level of earnings with a highest frequency. All the students assume most often their earnings from CZK 15,000 to CZK 20,000 for graduates and between CZK 20,000 to 30,000 after 10 years of experience.

The standard deviation of the estimates varies from CZK 6,000 till 36,000, which shows how the earnings are distributed. We can notice the difference between heterogeneity of the file of graduates and file of expectation after 10-year work experience. The results show a lower heterogeneity of graduate's expectations. The students have a quite good and similar expectation, which means they have relatively enough information about the situation on the labour market. The heterogeneity of the estimates of respondent's expectation after 10 years of experience is significantly higher.

Table 6 brings a detailed description of the data from academic year 2002/2003. In this case the modus value for all the graduates are assumed most often between CZK 15,000 and CZK 20,000 too and between CZK 25,000 and 35,000 after 10 years of experience, which means slightly higher than in the first academic year.

Table 6

Description of the data from questionnaire in $2002 / 2003$

\begin{tabular}{|l|c|c|c|c|c|c|c|c|}
\hline \multirow{2}{*}{$\begin{array}{l}\text { Characte- } \\
\text { ristics }\end{array}$} & \multicolumn{4}{|c|}{ Public universities } & \multicolumn{3}{c|}{ Earnings level (in CZK) } \\
\cline { 2 - 9 } & \multicolumn{2}{|c|}{ Male } & \multicolumn{2}{c|}{ Female } & \multicolumn{2}{c|}{ Male } & \multicolumn{2}{c|}{ Female } \\
\cline { 2 - 9 } & Graduates & $\begin{array}{c}10 \text {-year work } \\
\text { experience }\end{array}$ & Graduates & $\begin{array}{c}10 \text {-year work } \\
\text { experience }\end{array}$ & Graduates & $\begin{array}{c}10 \text {-year work } \\
\text { experience }\end{array}$ & Graduates & $\begin{array}{c}\text { 10-year work } \\
\text { experience }\end{array}$ \\
\hline Average & 23,627 & 42,961 & 16,677 & 32,591 & 19,971 & 42,121 & 15,103 & 25,621 \\
\hline $\begin{array}{l}\text { Mean signed } \\
\text { error }\end{array}$ & 1,553 & 2,237 & 314 & 2,032 & 1,254 & 5,972 & 841 & 1,862 \\
\hline Median & 20,000 & 35,000 & 15,000 & 25,000 & 19,000 & 30,000 & 15,000 & 22,000 \\
\hline Modus & 20,000 & 35,000 & 15,000 & 25,000 & 20,000 & 25,000 & 15,000 & 30,000 \\
\hline $\begin{array}{l}\text { Standard } \\
\text { deviation }\end{array}$ & 19,275 & 27,765 & 5,942 & 38,498 & 7,313 & 34,305 & 4,530 & 10,026 \\
\hline Variance & $371,521,443$ & $770,903,701$ & $35,304,520$ & $1,482,133,541$ & $53,483,957$ & $1,176,859,848$ & $20,524,631$ & $100,529,557$ \\
\hline $\begin{array}{l}\text { Difference } \\
\text { max-min }\end{array}$ & 143,000 & 165,000 & 54,000 & 591,000 & 32,000 & 136,000 & 17,000 & 45,000 \\
\hline Minimum & 7,000 & 15,000 & 6,000 & 9,000 & 8,000 & 14,000 & 8,000 & 15,000 \\
\hline Maximum & 150,000 & 180,000 & 60,000 & 600,000 & 40,000 & 150,000 & 25,000 & 60,000 \\
\hline Number & 154 & 154 & 360 & 360 & 34 & 34 & 29 & 29 \\
\hline $\begin{array}{l}\text { Confidence } \\
\text { level } \\
\text { (95.0\%) }\end{array}$ & 3,069 & 4,420 & 617 & 3,996 & 2,552 & 12,164 & 1,723 & 3,814 \\
\hline
\end{tabular}

Source: Own calculations.

The standard deviation of the estimates varies from CZK 4,500 till 38,500, which shows how the earnings are distributed. Also in this case the students have a quite good and similar expectation, which means they have relatively enough information about the situation on the labour market.

Investment of time and resources in the formation of human capital increase the productive potential of workers (and increase as well consumer benefits and leisure) that are realized over a lifetime. Measuring the internal rate of returns to human capital calls for an analysis of costs and benefits of birth cohorts over their lifetimes. Most data pertain to cross sections, however, that describe inputs and outcomes in 
one period of time across different individuals grouped by age. Demographers recognize the limitations of such synthetic construction from cross-sectional data designed to represent cohort experiences over time. Assumptions are necessary to translate cross-sectional evidence into human capital lifetime investment returns (see Mincer, 1974). The situation in the Czech Republic faces the lack of data suitable for identification of rate of return from investment into education. The Czech Statistical Office and Ministry of Labour and Social Affairs provide only incomplete statistics and do not focus on the differentiation according to the level of education in civil servant sphere. To calculate private internal rate of return we used data from the statistical survey of Ministry of Labour and Social Affairs (2004) for business sphere as well as the data from our own survey. The following equation was used for this calculation.

$$
r_{s}=\frac{A E_{i}-A E_{j}}{k \cdot S \cdot A E_{j}}
$$

where $A E_{i}=$ average gross income of people with the university degree, $A E_{i}=$ average gross income of people with secondary level education, $k=$ coefficient that equals $1, S=$ number of years spent at the university, $r_{s}=$ private rate of return of investment into education.

For the business sphere was used this equation with the data:

$$
r_{s}=\frac{32733-16850}{1 \cdot 5 \cdot 16850}=0.19 \times 100=19.0 \%
$$

The result of $19.0 \%$ confirms previous assumptions about a high rate of return of this investment.

\section{Private Universities}

The calculation of private rate of return of private university students has been done for academic year 2002/2003. Graduates who answer in our survey expect following rate of return:

$$
r_{s}=\frac{1770-11278}{1 \cdot 5 \cdot 11278}=0.1144 \text { it means: } 11.44 \%
$$

After ten years of employment of these students, the private rate of return increases slightly:

$$
r_{s}=\frac{34403-21032}{1 \cdot 5 \cdot 21032}=0.1252 \quad \text { it means: } 12.52 \%
$$

\section{Public Universities}

It is quite surprising that students of public universities expect their private rate of return even higher than their colleagues from private universities. Graduates who answer in our survey expect following rate of return:

$$
r_{s}=\frac{18780-10334}{1.5 \cdot 10334}=0.1634 \quad \text { it means: } 16.34 \%
$$

After ten years of employment of these students, the private rate of return increases slightly:

$$
r_{s}=\frac{35744-16610}{1 \cdot 5 \cdot 16610}=0.2304 \text { it means: } 23.4 \%
$$


These results can be concluded in a statement that in both cases the private rate of return was very high as we expected. The level of rate of return is much higher than the interest which we could get in any Czech bank if we invest our money there. Even for the students of private universities who have to pay tuition the rate of return is high enough to study the university instead of participating on the labour market.

Table 7

Rate of Returns to Education according to the Level of Education (in \%)

\begin{tabular}{|l|c|c|c|c|c|c|}
\hline & \multicolumn{3}{|c|}{ Social } & \multicolumn{3}{c|}{ Private } \\
\hline Region & Primary & Secondary & Tertiary & Primary & Secondary & Tertiary \\
\hline Asia1) & 16.2 & 11.1 & 11.0 & 20.0 & 15.8 & 18.2 \\
\hline $\begin{array}{l}\text { Europe/Middle } \\
\text { East. North } \\
\text { Africa1) }\end{array}$ & 15.6 & 9.7 & 9.9 & 13.8 & 13.6 & 18.8 \\
\hline $\begin{array}{l}\text { Latin America/ } \\
\text { Caribic }\end{array}$ & 17.4 & 12.9 & 12.3 & 26.6 & 11.7 & 19.5 \\
\hline OECD & 8.5 & 9.4 & 8.5 & 13.4 & 11.3 & 11.6 \\
\hline $\begin{array}{l}\text { Sub-Saharan } \\
\text { Africa }\end{array}$ & 25.4 & 18.4 & 11.3 & 37.6 & 24.6 & 27.8 \\
\hline World total & 18.9 & 13.1 & 10.8 & 26.6 & 17.0 & 19.0 \\
\hline
\end{tabular}

1) Non-members of OECD.

Source: Psacharopoulos, Patrinos, 2002.

As we already mentioned many other empirical research has been already done in the sphere of return of investment in education. The data given by Psacharopoulos and Patrinos analysis is in the following figure. According to authors there is the private rate of return to higher education about $19.0 \%$, the level of social rate of return is than slightly lower, about $10 \%$, which is caused by involvement of social costs in the education.

It can be seen that higher education offers attractive returns on investment and it creates opportunities for owners of the capital to finance the students' costs. Student loans are a traditional mechanism used for that purpose but there are many barriers for financing higher education costs through loans. First of all, education investment is very illiquid. If the investor invests in the house through the mortgage the house can be held as collateral for the loan. On the other hand a student cannot sell himself or offer himself as collateral for an investment. Second important reason for financial market failure in the financing of higher education is the uncertainty and intangible nature of human capital. Some students fail to complete their studies or they choose that type of studies return of which is quite low (social work, education, arts, etc.). Moreover, investors cannot know exactly the intentions of the students and some of students can default the payments for simple reason of unwillingness to earn money.

Another possibility how to address market failure in financing higher education is income-contingent loans. In this case students repay their loan after graduation and their repayments depend on the level of their income. However, income-contingent loans differ from human capital contracts in one important feature - student has to repay his/her loan even if he/she earns low salary because the repayment is a fixed sum. It is true that some systems of income-contingent loans have stipulati- 
ons which free graduates from the duty to repay complete their loans after some period (e.g. Australia) but mostly the repayment must be fully repaid. On the other hand human capital contracts reflect students' ability to pay and the repayments are limited to contracted period. Once this period is over the obligation is also over regardless of what has been paid.

The mechanism of human capital contracts creates usually an obligation of students to repay the investment for contracted limited period, to pay some percentage of their income during this period. Repayments start after graduation and last for the contracted period. After this period, students are completely free from their obligations.

\section{Human Capital Contracts and Czech Banks}

As the costs of living and direct cost of higher education continue to increase (and also the tuition and fees at private universities) and more students and their families will invest even larger portions of their income in a college education and many will incur large amounts of debt. An alternative way to pay for a college education in the Czech Republic is through higher education loans. Student loans can effectively increase access to higher education for students from all lower society classes.

Student loans are a form of credit intended for students to cover their expenses for books, computers, tuition, etc. Students get an amount of money (usually ranging from tens of thousands to some hundreds of thousands korunas) and they start to pay off the loan after they finish the degree and find a job.

Table 8

Offer of the Student Loans on the Czech Financial Market

\begin{tabular}{|l|c|c|c|c|c|c|}
\hline Bank & $\begin{array}{c}\text { Name of } \\
\text { product }\end{array}$ & $\begin{array}{c}\text { Student's } \\
\text { loan }\end{array}$ & $\begin{array}{c}\text { Interest } \\
\text { rate (in \%) }\end{array}$ & $\begin{array}{c}\text { Payback } \\
\text { period in } \\
\text { years }\end{array}$ & $\begin{array}{c}\text { Student's } \\
\text { current } \\
\text { account } \\
\text { credit (CAC) }\end{array}$ & $\begin{array}{c}\text { Interest rate } \\
\text { of CAC } \\
\text { (in \%) }\end{array}$ \\
\hline $\begin{array}{l}\text { Komerční } \\
\text { banka }\end{array}$ & Gaudeamus & $\begin{array}{c}50,000- \\
500,000\end{array}$ & $7-9$ & $1-10$ & 10,000 & $12 / 25$ \\
\hline $\begin{array}{l}\text { Česká } \\
\text { spoŕitelna }\end{array}$ & $\begin{array}{c}\text { Cash loan } \\
\text { for university } \\
\text { students }\end{array}$ & max. 80,000 & 9.9 & $1-10$ & $\begin{array}{c}5,000 / \\
10,000 / \\
20,000^{3)}\end{array}$ & $12.9 / 25$ \\
\hline $\begin{array}{l}\text { Československá } \\
\text { obchodní banka }\end{array}$ & $\mathrm{x}$ & $\mathrm{x}$ & $\mathrm{x}$ & $\mathrm{x}$ & 6,000 & $12 / 15$ \\
\hline E-Banka & $\mathrm{x}$ & $\mathrm{x}$ & $\mathrm{x}$ & $\mathrm{x}$ & 10,000 & $13 /$ n.a. \\
\hline Volksbank & $\mathrm{x}$ & $\mathrm{x}$ & $\mathrm{x}$ & $\mathrm{x}$ & $\mathrm{x}$ & $\mathrm{x}$ \\
\hline $\begin{array}{l}\text { Sparkasse } \\
\text { Mühlviertel - } \\
\text { West banka, a.s. }\end{array}$ & Loan for & 300,000 & n.a. & n.a. & $\begin{array}{c}10,000 \\
20,000\end{array}$ & n.a. \\
\hline Reiffeisen & $\mathrm{x}$ & $\mathrm{x}$ & $\mathrm{x}$ & $\mathrm{x}$ & n.a. & $24.8 \%{ }^{4)}$ \\
\hline
\end{tabular}

1) The interest rate in 2003.

2) Authorized unsecured debit / non-authorized debit.

3) Depends on the type of school and year, which the student studies.

4) Interest rate for current account (not student).

Source: www pages and bank information. 
The situation with student loans is not very optimistic on the Czech financial market. There is a big offer of mortgages and loans for other clients on our financial market and this situation is comparable with other countries worldwide. On the other hand, Czech banks are not very well prepared to offer sufficient financial instruments to Czech students for financing higher education.

On the Czech market, there are only two banks, which are able to offer a student's loan. Some of the others provide for the students current account credits. Unfortunately this possibility is very limited in the amount of money they can get and also conditions for paying off this form of credit are constraining.

Komerční banka was a first bank on the Czech financial market which came with the offer for students to get a loan for education. Students can get there a loan between CZK 50,000 and CZK 500,000 (cca EUR 1,600 - 16,000), usually with the interest rate between $7 \%$ and $9 \%$. The situation is different, when the student expects to pay the loan off after his/her studies. In this case the maximum of the money available is much lower and is limited with CZK 150,000 (EUR 5,000). The loan entitled "Gaudeamus" (see Table 8 ) is provided only on condition that the students have a current account in this bank and are older than 18 years. Besides the university students (bachelor, master and PhD degree) also students from collages can apply for this account and the Gaudeamus loan.

More recently, also Česká spořitelna came with the offer of student loans. In comparison with Komerční banka, Česká spořitelna is even more strict in terms of the loan. The maximum amount of money which students can get is CZK 80,000 (cca EUR 2,300) and the student has to be at least in the third academic year at the university. Also this bank requires having a current account before the student applies for the loan. These student's current accounts are usually on accommodating terms with minimum banking charges and with a better interest rate. The interest rate for the student loan is about $9.9 \%$. Both banks will demand a creditor (or joint debtor), which is usually one of the parents of the student.

There is one more bank in the Czech Republic - Sparkasse Mühlviertel - West banka, a.s., which offers student's loans up to CZK 300,000 (EUR 10,000). This bank cannot influence the whole Czech financial market because its sphere of action is very limited and this bank has got just several branches in the region of south Bohemia. Another bank, which had offered loans for students on the Czech financial market was Československá obchodní banka. Unfortunately this bank has suspended administration of student's loans since January 1, 2001.

All the other banks on the financial market in the Czech Republic do not offer any student loan. Nevertheless, there is another possibility for the students to get a limited amount of money available together with their current accounts. The individual who has a student's current account with an active balance for a given period (it is different for an individual bank), can usually also get a current account credit with it. The limits of current account credits are listed in the Table 8 above and it is up to CZK 20,000 (EUR 650). The money from this account is not calculated only for activities connected with studying but because it depends on the student's account existence, it can be considered as a form of student's loan, too. The current account credits are usually charged with a quite high interest rate (in comparison with other credits, loans and mortgages) and therefore are used usually for the bridging of short-term financial embarrassments.

It is very important to prepare legal conditions for financial instruments on the Czech financial market, it means for student's loans but also for potential human capital contracts. Legal condition should ensure protection for all sides - investors, student's loan lenders and students. The protection comes from the recognition of 
the validity of the loan contract and from denying students the possibility to reject their obligation if they file for bankruptcy.

Human capital contracts are a new instrument for financing higher education. At the time being, we know about two organizations offering the possibility to obtain money for university studies through this type of investment. However, we believe that this tool could be implemented in the Czech Republic and could create good opportunity for the students to finance their share of higher education costs.

\section{Slovak Higher Education System}

The higher education went through several changes in Slovakia since 1993 and in the Czech Republic, too. Nevertheless, both systems of the public higher education system from one model and are fully dependent on the state budget.

System of the financial support of university students in Slovakia. Poorer families have to solve problems how to finance education for their children. More than half of the families in Slovakia suppose that university studies influence their budget deeply. Therefore the government tries to solve this situation with different forms of support for the socially week families.

Scholarships. The most common ways how to get any scholarship in Slovakia are from the state sources (mostly social scholarships) and other sources, which are usually funds of universities for all the students without differences.

Social scholarship from the state sources. There are some facts about social scholarships from the state sources in Slovakia:

- each university makes from own sources scholarship fund for the student support, its using is strictly directed by the "scholarship rules";

- the aim of this scholarship is to help students in difficult social conditions and it is paid according to the binding regulation of the Ministry of Education. The main criteria are the average income per person in family of an applicant.

Table 9

Social Scholarships in Slovakia (in SKK)

\begin{tabular}{|c|c|c|}
\hline \multicolumn{2}{|c|}{ income per one family member } & monthly scholarship \\
\hline & $>2,700$ & 2,000 \\
\hline$<2,700$ & $>3,200$ & 1,500 \\
\hline$<3,200$ & $>3,700$ & 1,000 \\
\hline
\end{tabular}

Source: Sulanová, Zvalová, 2003.

Table 10

Number of Scholarships and the Financial Means Paid from the State Budget for the Social Scholarships

\begin{tabular}{|c|c|c|}
\hline Year & Average number of scholarships & Scholarship in SKK \\
\hline $1997 / 1998$ & 978 & $8,738,590$ \\
\hline $1988 / 1999$ & 795 & $8,049,608$ \\
\hline $1999 / 2000$ & 877 & $7,423,180$ \\
\hline $2000 / 2001$ & 1,844 & $24,052,559$ \\
\hline $2001 / 2002$ & 5,225 & $80,857,350$ \\
\hline
\end{tabular}

Source: Statistical Yearbook for Education 1998 - 2002. 
Scholarships from own sources depend on the current situation of the university; these scholarships are based on the rules of each university, mainly they are given to students with excellent studying results, research or sport activities.

State loans with the fixed interest. State loans are available for students to pay their studying expenses in Slovakia and abroad. These loans can gain only a small per cent of all the Slovak students and the law stipulates conditions for loan applications. In general, a student who applies for the state loan has to be an excellent student or a student with some disability or from a family, which has a lower income that the minimal wage for a given period in Slovakia. There is special organization "Students Loan Fund" appointed as a manager of these funds.

The repayment period is 10 years after signing the contract. The highest amount which can any student get is SKK 40,000 (EUR 1,250) for one academic year and the longest period to have this loan is for 6 academic years. Security of the loan is through the guarantor who has to be younger than 50 years. The interest for this loan is subsidized by the state and is only $3 \%$ per annum.

Short-term credits from commercial banks. There are only few banks on the Slovak financial market that offer short-term credits for the students. Some examples can be found in the Table 11. All these products are very similar and depend on an individual client, which product he or she chooses.

Table 11

Comparison of Student's Accounts in the Slovak Commercial Banks

\begin{tabular}{|c|c|c|c|c|c|c|c|c|c|}
\hline BANK & $\begin{array}{c}\text { Banka } \\
\text { Slovakia } \\
\text { a.s. }\end{array}$ & ČSOB & $\begin{array}{l}\text { Dexia } \\
\text { Banka } \\
\text { a.s. }\end{array}$ & $\begin{array}{c}\text { HVB } \\
\text { Bank } \\
\text { Slovakia }\end{array}$ & $\begin{array}{l}\text { Istro- } \\
\text { banka } \\
\text { a.s. }\end{array}$ & $\begin{array}{c}\text { Ludová } \\
\text { banka } \\
\text { a.s. }\end{array}$ & $\begin{array}{c}\text { OTP } \\
\text { Banka } \\
\text { a.s. }\end{array}$ & $\begin{array}{c}\text { Slovenská } \\
\text { sporitelňa } \\
\text { a.s. }\end{array}$ & $\begin{array}{c}\text { UniBanka } \\
\text { a.s. }\end{array}$ \\
\hline Age limit & 26 & 26 & 26 & 26 & 26 & 25 & 26 & 26 & 26 \\
\hline $\begin{array}{l}\text { Minimal } \\
\text { balance } \\
(\mathrm{SKK})\end{array}$ & 100 & - & 100 & - & 150 & 1,000 & 200 & - & 300 \\
\hline $\begin{array}{l}\text { Account } \\
\text { opening }\end{array}$ & $\begin{array}{c}\text { free } \\
\text { of charge }\end{array}$ & $\begin{array}{c}\text { free } \\
\text { of charge }\end{array}$ & $\begin{array}{c}\text { free } \\
\text { of charge }\end{array}$ & $\begin{array}{c}\text { free } \\
\text { of charge }\end{array}$ & $\begin{array}{c}\text { free } \\
\text { of charge }\end{array}$ & $\begin{array}{c}\text { free } \\
\text { of charge }\end{array}$ & $\begin{array}{c}\text { free } \\
\text { of charge }\end{array}$ & $\begin{array}{c}\text { free } \\
\text { of charge }\end{array}$ & $\begin{array}{c}\text { free } \\
\text { of charge }\end{array}$ \\
\hline $\begin{array}{l}\text { Account } \\
\text { fees }\end{array}$ & $\begin{array}{c}\text { free } \\
\text { of charge }\end{array}$ & $\begin{array}{c}\text { free } \\
\text { of charge }\end{array}$ & $\begin{array}{c}\text { free } \\
\text { of charge }\end{array}$ & $\begin{array}{c}\text { free } \\
\text { of charge }\end{array}$ & $\begin{array}{c}\text { free } \\
\text { of charge }\end{array}$ & for fee & $\begin{array}{c}\text { free } \\
\text { of charge }\end{array}$ & $\begin{array}{c}\text { free } \\
\text { of charge }\end{array}$ & $\begin{array}{c}\text { free } \\
\text { of charge }\end{array}$ \\
\hline $\begin{array}{l}\text { Overdraw } \\
\text { (SKK) }\end{array}$ & no & 6,000 & 20,000 & 10,000 & no & no & no & 20,000 & 5,000 \\
\hline Benefits & & $\begin{array}{c}\text { ISIC } \\
\text { Card, } \\
\text { compe- } \\
\text { titions }\end{array}$ & $\begin{array}{l}\text { compe- } \\
\text { titions }\end{array}$ & & & $\begin{array}{l}\text { ISIC } \\
\text { Card }\end{array}$ & $\begin{array}{l}\text { compe- } \\
\text { titions }\end{array}$ & & \\
\hline $\begin{array}{l}\text { Loan/over- } \\
\text { draw } \\
\text { interest } \\
\text { (in \%) }\end{array}$ & n.a. & Contract & 10.7 & 8.5 & n.a. & n.a. & n.a. & 9.85 & 9.5 \\
\hline $\begin{array}{l}\text { Credit } \\
\text { interest } \\
\text { (in \%) }\end{array}$ & Contract & Contract & 1.8 & Contract & 1 & 1 & 2.6 & 1.15 & 1 \\
\hline Guarantor & no & no & yes & yes & no & no & no & yes & no \\
\hline
\end{tabular}

Middle-term credits from commercial banks. There is still a big discussion about paying tuition and in connection with it banks do not hurry up with some special offer of credits for the students. Nevertheless, there are already some banks, 
which offer these products. There is an example of Slovenská spořitelna, a.s. and UniBanka, a.s. These credits are both for students between 18 and 26 years who study in the second or higher academic year and are full time students. They have to be permanent residents of the Slovak Republic and have a current bank account in these banks. The comparison of the banks brings Table 12.

Table 12

Middle-term Credits from Commercial Banks

\begin{tabular}{|c|c|c|c|c|c|}
\hline $\begin{array}{c}\text { Name of the } \\
\text { institution }\end{array}$ & $\begin{array}{c}\text { Minimum } \\
\text { in SKK }\end{array}$ & $\begin{array}{c}\text { Maximum } \\
\text { in SKK }\end{array}$ & $\begin{array}{c}\text { Payback } \\
\text { period/years }\end{array}$ & Security & Interest (in \%) \\
\hline $\begin{array}{c}\text { Slovenská } \\
\text { spořitelna, a.s. }\end{array}$ & 50,000 & 150,000 & $5^{2)}$ & $\begin{array}{c}2 \text { surely } \\
\text { properties } \\
\text { receivables }\end{array}$ & 8.3 \\
\hline UniBanka, a.s. & 0 & 70,000 & 5 & $\begin{array}{c}\text { Co-applicant } \\
\text { life insurance } \\
\text { shares, bonds }\end{array}$ & $10-11.5$ \\
\hline
\end{tabular}

1) After graduation.

2) Maximum 10 years after the credits were signed.

The student's loan in the Slovenská spořitelna is available with lower interest, it offers bigger amount of money. The UniBanka on the other hand requires lower security - better availability and there is not a minimum amount of the credit.

\section{Conclusions}

The paper provides the information about the situation in the higher education in the Czech Republic and Slovak Republic. As we can see there is a structure of private and public universities with different system of funding. Sources available for any financial support of students are very limited in the Czech Republic and Slovakia in comparison with an offer of instruments in other countries.

The private rate of return counted from the data of our pilot survey concerning the expectations of students in the Czech public and private universities confirmed a high private rate of return, comparable with the results given e.g. by Psacharopoulos or Patrinos. It is surprising that students of public universities with no tuition fees expect even higher returns after their graduation than the students of private universities. We can conclude that also our research confirmed general assumption about human capital investment associated with significant labour-market gains for the individuals, society, chances of higher participation in the labour market and improvement of the employment probability.

For the future of Czech financial market, it is necessary to bring more opportunities for students, particularly for students from lower-income households to pursue higher education. The fact that education offers attractive returns on investment should create opportunities for those who possess the capital to finance the education of students. The traditional mechanism for this purpose is a student loan, but the nature of student financing creates some barriers that prevent the development of the natural flow of private capital in a form of loans in this area. As a result there are not enough offers available for students who want to finance their studies. Human capital contracts give new opportunities for both students and investors to create dynamic, highly profitable and safe financial market. At the same time, distributive consequences of this financial tool are positive. 
Barbaro, S. (2002), "The Distributional Impact of Subsidies to Higher Education - Empirical Evidence from Germany." Proceedings of the 58th Congress of the International Institute of Public Finance. Helsinki, Government Institute for Economic Research (http://data.vatt.fi/iipf2002).

Barro, R. J., Sala-i-Martin, X. (2004), Economic Growth, 2nd Ed. Cambridge (MA): MIT Press.

Becker, G. S. (1993), Human Capital. A Theoretical and Empirical Analysis, with Special Reference to Education. Chicago: University of Chicago Press.

(1997), Teorie preferencí. Prague: Grada.

Belfield, C. R. (2000), Economic Principles for Education. Cheltenham: Edward Elgar.

CSO (2004), Statistical Yearbook of the Czech Republic 2004. Prague: Czech Statistical Office.

Dearling, R. (Chairman) (1997), Higher Education in the Learning Society (Summary Report of the National Committee of Inquiry into Higher Education). London: Crown.

Domintz, J., Manski, Ch. F. (1994), "Eliciting Student Expectations of the Returns to Schooling." Cambridge, MA, National Bureau of Economic Research (NBER Working Paper Series No. 4936).

Filer, R. K., Jurajda, S., Plánovský, J. (1998), "Returns to the Market: Valuing Human Capital in the Post-Transition Czech and Slovak Republics." Prague, CERGE/EI Working Paper No. 125 (http:// www.cerge-ei.cz/pdf/wp/Wp125.pdf).

Glomm, G. (1993), "Parental Choice of Human Capital Investment." Prague, CERGE/EI Working Paper No. 39 ( http://www.cerge ei.cz/publications/working_papers/abstract/039.asp).

Madies, T., Ventelou, B. (2000), "How to Finance Public Education?" Proceedings of the 56th Congress of the International Institute of Public Finance. Seville, University of Seville.

McMahon, W. W. (1987), "Expected Rates of Returns to Education," in Psacharopoulos, G., ed., Economics of Education. Research and Studies. Oxford: Pergamon Press, pp. 187- 195.

(1987), "Student Labor Market Expectations," in Psacharopoulos, G., ed., Econo-

mics of Education. Research and Studies. Oxford: Pergamon Press, pp. 182-186.

Mincer, J. (1974), Schooling, Experience and Earnings. New York: Columbia University Press. (1993), Studies in Human Capital. Aldershot: Edward Elgar.

MLSA (2004), "Information System about Average Earnings." (ISPV) [online]. Prague: Ministry of Labour and Social Affairs (http://www.mpsv.cz/scripts/clanek.asp?lg=1\&id=682).

Nepolská, K. (2000), "Does the Czech Republic Realize the Importance of Human Capital within our EU Accession?" Proceedings Tempus "Česká republika a Evropská unie na prahu třetího tisíciletí". Zlín, UTB.

Nepolská, K., Urbánek, V. (2003), "Higher Education as a Mixed Good: Its Provision at Public and Private Institutions and Consequences for Returns on Private Investment. " Ekonomie a Management, 6, Special Issue, pp. 16-21.

OECD (2001), Education at a Glance - OECD Indicators 2001. Paris: OECD. (2002), Education at a Glance - OECD Indicators 2002. Paris: OECD. (2003), Education at a Glance - OECD Indicators 2003. Paris: OECD.

Operational Manual for ISCED (1997) International Standard Classification of Education. Geneve: UNESCO.

Palacios, M. (2002), Human Capital Contracts - 'Equity-like' Instrument for Financing Higher Education. Washington DC: Cato Institute (http://www.cato.org/pubs/pas/pa-462es.html).

Patrinos, H. A. (2004), "Innovative Education Funding Worldwide", in O'Halloran, E. F. et al., eds., Financing Human Capital. Charlottesville, VA, Darden Business Publishing, pp. 3-15.

Polachek, S. W. (1995), "Earnings over the Life Cycle: What Do Human Capital Models Explain?" Scottish Journal of Political Economy, 42 (3), pp. 267-289.

Psacharopoulos, G. (1995), "The Profitability of Investment in Education: Concepts and Methods." New York, World Bank (http://www-wds.worldbank.org/servlet/WDSContentServer/ WDSP/IB/1995/ 11/01./000009265_3961019163739/Rendered/PDF/multi_page.pdf).

Psacharopoulos, G., Patrinos, H. A. (2002), "Returns to Investment in Education: A Further Update." Washington DC: World Bank Policy Research Working Paper No. 2881 (http://econ.worldbank.org).

Schultz, P. T. (2003), "Human Capital, Schooling and Health Returns." New Haven, Yale University, Centre Discussion Paper No. 853 (http://ssrn.com/abstract=392781).

SSO (1998-2002), Statistical Yearbook for Education (in Slovak). Bratislava: Slovak Statistical Office. 
Sulanová, M., Zvalová, M. (2003), Social Situation of Full-time University Students in Slovakia (in Slovak). Bratislava: Institute for Information and Prognoses in Education (http://www.poplatky.kis.sk/ dokumenty/Socialnepostavstudentov.pdf).

Urbánek, V. (1994), "Changes in Funding of Higher Education in the Czech Republic." European Journal of Education, 29(1), pp. 75-83.

Urbánek, V., Nepolská, K. (2002), "Higher Education As a Mixed Good: Its Provision at Public and Private Institutions and Consequences for Returns on Private Investment." Proceedings of the 58th Congress of the International Institute of Public Finance. Helsinki: Government Institute for Economic Research (http://data.vatt.fi/iipf2002).

(2003), "Human Capital Measurement in the International Context: Expected Returns to Higher Education in Selected Countries." Proceedings of the 7th Conference on International Human Resource Management Dublin.

Urbánek, V., et al. (2002), "Public Finance and Infrastructural Investment in the Czech Republic in the Period of Transition." Athens, University of Georgia.

Williams, G. (1992), Changing Patterns of Finance in Higher Education. Buckingham: Open University Press.

Wolter, S. C., Weber, B. A. (2000), "Returns to Education: Are Student's Expectations Rational?" Proceedings of the 56th Congress of the International Institute of Public Finance. Seville, University of Seville.

Woodhall, M. (1987), "Human Capital Concepts", in Psacharopoulos, G., ed., Economics of Education. Research and Studies. Oxford: Pergamon Press, pp. 21-24.

http://www.csas.cz

http://www.csob.cz

http://www.ebanka.cz

http://www.kb.cz

http://www.rb.cz

http://www.smw.cz

http://www.volksbank.cz 